\title{
Influence of the Decisions of the European Court of Human Rights on the Legal Order of Bosnia and Herzegovina in Terms of Exercising Same Sex Unions
}

\author{
Boris Krešić ${ }^{1}$, Zlatan Begić ${ }^{1}$, Jasmina Alihodžić ${ }^{1} \&$ Dženeta Omerdić ${ }^{1}$ \\ ${ }^{1}$ Faculty of Law, Tuzla University, Bosnia and Herzegovina \\ Correspondence: Zlatan Begić, Faculty of Law, Tuzla University, Bosnia and Herzegovina. E-mail: \\ zlatan.begic@untz.ba
}

Received: July 2, 2017

Accepted: September 14, 2017

Online Published: November 29, 2017

doi:10.5539/jpl.v10n5p56

\author{
URL: https://doi.org/10.5539/jpl.v10n5p56
}

\begin{abstract}
The achievement of rights of same-sex couples is an actual topic in contemporary law. This is especially in focus of the professional and academic publicity in the transitional countries such as Bosnia and Herzegovina. In this paper authors considered the issue of the achievement of the same-sex couples' rights in the legal system of this country in the context of the European Court of Human Rights practice and obligations arising from the European Convention on Human Rights and its Protocols. The aim of this paper is to determine to which extent the national legal order of Bosnia and Herzegovina, the country trying to accede to European integration, implements european standards of human rights and freedoms with the final goal to point to the omissions and possible directions for reform.
\end{abstract}

Keywords: same sex civil union, European Court of Human Rights, right to family life, private international law aspects of same-sex civil unions, Bosnia and Herzegovina

\section{Introduction}

The European Court of Human Rights (hereinafter ECtHR) has a rather broad definition of the term 'family life' in Article 8 of the European Convention on Human Rights (hereinafter ECHR), considering family life to be essentially the fact that depends on the real existence of close personal relations. When deciding on whether a relationship may be regarded as a family life, the ECtHR considers a whole set of factors. Taking into consideration the social and legislative changes in the countries signatories of the ECHR, the ECtHR expanded the definition of family life outside the scope of formal relationships, meaning the de iure family life, in a sense that the term of family life pursuant to Article 8 of the European Convention is actually defined as de facto family life. Same sex civil unions are given increasing protection by the ECtHR, whose protection is secured within the right to respect private life or in the context of non-discrimination. The ECtHR explicitly stated that the list of grounds for non-discrimination, as specified in Article 14 of the ECHR, is not complete but rather illustrative and that the provision of Article 14 of the Convention is to have a wide interpretation. Such interpretation thus paves the way to recognizing homosexual persons the right to respect for private life and consequently prohibits discrimination based on sexual orientation in any segment of life.

In accordance with the Article II/2 of the Constitution of Bosnia and Herzegovina (hereinafter BH) the ECHR and its Protocols are an integral part of the BH legal order and have priority over all other law. This paper provides considerations related to the legal status of the homosexual persons as well as an impact of the decisions of the ECtHR on the BH legal order in terms of exercising same sex unions.

\section{The Notion of Family in the Practice of the European Court of Human Rights}

The ECtHR developed the notion of family in accordance to the views of the European society. In its practice, the Court has established that the term "family life" is not limited solely to the families based on marriage but can include other de facto relationships. When deciding if a relationship can be regarded as a "family life", various factors are considered relevant, including the fact whether the couple lives together, the length of their relationship or whether they showed commitment to each other by having children together or in some other 
way. ${ }^{1}$ In the case Karner v. Austria ${ }^{2}$, the ECtHR answered the question if the family needs to be considered in a traditional sense with the following conclusion "The goal to protect family in a traditional sense is rather abstract and there is a broad range of concrete/specific measures to be used for the realization of this goal.In cases in which the margin of appreciation afforded to States is narrow, as is the position where there is a difference in treatment based on sex or sexual orientation, the proportionality principle does not only require the measure selected to be appropriate for the realization of the desirable objective, it also needs to show that the realization of that objective required the exclusion of certain categories of people. ${ }^{3}$ Tradition is not a legitimate reason (there has also been a long tradition of discrimination of women, ethnic and religious minorities), it only sends a symbolic message that same sex couples have less rights than heterosexual couples. Regarding the protection of the rights of homosexual persons, the ECtHR first protected the right to privacy ${ }^{4}$ and then the right to family life.

In the case Schalk and Kopf v. Austria, the ECtHR took the view that same sex civil unions fall into the term of family life. The ECtHR observes that since 2001, when the verdict in the case Mata Estevez was brought, many member states have faced a massive evolution of the attitude towards same sex partners. Ever since, a significant number of member states have allowed for the legal recognition of same sex civil unions. Certain regulations of the European Union (EU) also indicate a growing tendency for the inclusion of same sex couples in the term "family". In the context of this evolution, the ECtHR finds it artificial to retain the view that unlike the heterosexual couples, the same sex couples are not entitled to "family life" pursuant to Article 8. Consequently, the relationship between the applicants, same sex couple living in a stabile de facto relationship, falls into the term "family life", the same as for the different sex couple". ${ }^{5}$ It should be mentioned that the ECtHR in this case started from the premise that pursuant to Article 12 of the ECHR as well as Article 14 in ref. to Article 8, the countries are still allowed to limit the contracting of marriage to same sex couples. The ECtHR believes that the countries enjoy a certain level of free evaluation of a specifically defined status provided by alternative means of legal recognition. ${ }^{6}$ Although the ECtHR stated in this case that the member states do not have the obligation of enabling same sex couples to contract a marriage, specifying the non-existence of violation of Article 8 in ref. to Article 14 of the ECHR. The ECtHR found that there are alternative ways for same sex couples to regulate their legal status, the same as or similar to marriage. As a consequence, the countries are obliged to provide same sex unions with those rights necessary for successful functioning of a stabile emotional union, meaning family life. The ECtHR explicitly mentioned the possibility for such practice to happen in future, all the more as the EU Chart of Human Rights has abandoned the present traditional definition of marriage as a heterosexual union and the increasing number of European countries has stipulated full marriage equality. ${ }^{7}$

In the case Vallianatos and Others vs.Greece ${ }^{8}$, the ECtHR also comments that in its verdict in the case Schalk and Kopf it took the view that due to growing evolution in a significant number of member states regarding the legal recognition of homosexual couples it would be artificial to keep the view that unlike heterosexual couple, homosexual couple would (not) be able to enjoy the right of respecting "family life" as specified in Article 8 . Accordingly, the Court believes that the mutual relations between the applicants in the given case fall into the terms "private life" and "family life", in the same way as for heterosexual couples in the same situation. ${ }^{9}$ The ECtHR emphasized the non-existence of a positive obligation on behalf of the state to provide some form of legally recognized same sex union. The Court here avoided a more specific treatment of the rights of same sex partners. The ECtHR established in this case different treatment of same sex and different sex couples by finding that the right to civil union is guaranteed solely to the heterosexual couples, whereby same sex couples are automatically excluded. This case did not concern the issue whether Greece has a positive obligation to provide civil union for same sex couples, but the case refers to the negative obligation (of a signatory party) to refrain

\footnotetext{
${ }^{1}$ Para 36, Case of X, Y AND Z v. The United Kindom (Application no. 21830/93)

${ }^{2}$ Case of Karner v. Austria (Application no. 40016/98)

${ }^{3}$ Para 41, Karner v. Austria.

${ }^{4}$ See Dudgeon v. the United Kingdom, 22 October 1981, Series A no. 45; Norris v. Ireland, 26 October 1988, Series A no. 142; Modinos v. Cyprus, 22 April 1993, Series A no. 259; Salgueiro da Silva Mouta v. Portugal, no. 33290/96, ECTHR 1999-IX; Fretté v. France, no. 36515/97, ECTHR 2002-I; E.B. v. France [GC], no. 43546/02, 22 January 2008; and Gas and Dubois v. France, no. 25951/07, ECTHR 2012.

${ }^{5}$ Para 93 i 94,Case of Schalkand Kopf v. Austria (Application no. 30141/04).CaseofP.B. and J.S. v. Austria (Application no. 18984/02). Para 29. i 30 .

${ }^{6}$ Para 108. Schalk and Kopf v. Austria.

${ }^{7}$ Para 29, P.B. i J.S. v. Austria.

${ }^{8}$ Case of Vallianatos and Others v. Greece (Applications nos. 29381/09 and 32684/09).

${ }^{9}$ Para 78 and 81, Vallianatos and Others v. Greece.
} 
from discrimination based on sexual orientation. The Court emphasized that same sex couples are equally capable for stabile and dedicated relations as heterosexual couples. It therefore concluded that the applicants are in the situation comparable to the one of the heterosexual couples regarding their need for legal recognition and protection of their relationship. ${ }^{10}$ Besides, the Court established that the new law apparently introduced different treatment based on sexual orientation due to the contracting of a civil union being allowed to heterosexual couples only.

The ECtHR in the case Oliariand Others vs. Italy, ${ }^{11}$ legally valid as of October 212015 , took the view that the countries signatories to the European Convention on the Protection of Human Rights and Fundamental Freedoms are obliged to pass the legal regulations that would ensure the legal recognition of stabile emotional unions of same sex persons and the appropriate level of rights required for efficient respect of the right to family life for such unions. The Court concluded that the consensus was still not reached in terms of the legal recognition of same sex civil unions and that the countries still enjoy a certain level of free evaluation when it comes to the legalization of such unions. In the case Schalk and Kopf the ECtHR was not in capacity to reproach Austria for not having legalized some form of same sex civil union due to the fact that Austria had already legalized registered partnership. ${ }^{12}$ However, since there is no option for same sex partners in Italy to contract a same sex civil union, the Court was obliged to establish the existence of country's positive obligation (so as to provide private and family life) for the creation of a legal frame which would enable same sex partners to have the recognized status in the home legislation. ${ }^{13}$ In its conclusion, the Court stated that Italy overstepped its field of free assessment and failed to fulfill its legal obligation in providing a legal framework by which it would enable same sex partners the recognition and protection of their unions in domestic law. ${ }^{14}$ Even though the sentence brought in the case Oliari and Others vs. Italy is legally binding only for Italy, it signals a significant development in the approach made by the ECtHR, which now confirms the significance of recognizing the rights of same sex couples. After the Oliarisentence it is evident that the signatory countries are obliged to provide the legal framework that would regulate the position and rights of the same sex unions in their societies. Moreover, the explanation of the Oliari sentence clearly shows that the countries which do not pass such laws violate the dignity of such unions and the ECHR. All this indicates the existence of the legal obligation on behalf of the legislative power to provide the appropriate legal position of the same sex unions.

\section{Legal Implications of the Decisions Brought by the European Court of Human Rights}

Human rights and freedoms defined by the ECHR and its Protocols are seen as a "living matter", with the reach of regulations included in these acts changed in the course of time through the practice of the ECtHR. The same is in the field of rights to private and family life where through individual cases the view of the Court has been created pertaining to the rights of the persons living in same sex unions. It is indisputable that the decisions of the ECtHR are of an individual character and related to individual cases. However, it is also indisputable that the ECtHR is the supreme court authority for the interpretation of the provisions of the ECHR and its Protocols, regardless of the fact that such interpretations are given in the form of individual decision.

The self imposed question is: Will the decisions of the ECtHR in individual cases have the general importance in terms of their influence on not only the rights and obligations at an individual level but also on the legislatures of the countries in which the ECHR and its protocols have the binding nature, as is in BH?

However, it would not be possible to defend the view which interprets that the ECtHR decisions are binding only for the parties involved at an individual level pursuant to individual legal act which provided grounds for initiating the procedure before this Court for the violation of rights and freedoms guaranteed by the ECHR. Such view would mean that the violation in question is related to an individual act which led to the violation of rights and freedoms in a concrete individual case and the reparation of its consequences, rather than the general act (law or by-law acts, in some cases even the Constitution) which served as the basis for the disputed individual act and is itself the very source of the violation. Actually, the decisions of the ECtHR, brought on the basis of an individual act, would indeed have to influence the general act serving as the foundation for the individual act that specified the violation of rights guaranteed by the ECHR. It is the fact that the ECtHR has no power to force the respondent state to alter or outlaw the general act serving as the source of the violation of rights and freedoms guaranteed by the ECHR. It is the ECtHR that acts via the power of its authority and its decisions can be used to remediate the

\footnotetext{
${ }^{10}$ Para 90, Vallianatos and Others v. Greece.

${ }^{11}$ Case of Oliari and Others v. Italy (Applications nos. 18766/11 and 36030/11).

12 Para 102, Schalk and Kopf v. Austria.

${ }^{13}$ Para 164, Oliari and Others v. Italy.

${ }^{14}$ Para 185. Oliari and Others v. Italy.
} 
consequences of a single - individual act, most often by specifying a concrete compensation for the damaged party. However, the role of the Court does not exhaust here. By international as well as domestic law, the established violations of the ECHR in individual cases oblige the respondent state not only to execute the decision in terms of eliminating the consequences suffered by an individually specified person - the plaintiff, but also to alter its general acts that actually gave the legal grounds for adopting the individual decision. Any different action would imply the continuation of the validity of the disputed general act with the possibility for violating the rights and freedoms of an unspecified number of persons in all similar cases in the future. This would be the circumvention of the role of the ECtHR and its decisions, since the general act serving as the basis for passing individual acts, by which the rights and freedoms guaranteed by the ECHR are violated, should be changed pursuant to the decisions of the ECtHR that established violation beyond doubt. This is particularly important due to the fact that the signatory states, having ratified and confirming validity of the ECHR, accepted the jurisdiction of the ECtHR and its legal position of the supreme court authority in terms of the interpretation and implementation of its provisions.

What seems to be the problem in the practice of some countries (BH for example) is that the decisions of the ECtHR are implemented at an individual level only. In such situations, the respondent state carries out the decisions of the ECtHR in terms of the compensation to the plaintiff as specified by the Court, but does nothing in terms of any possible changes to the general act (constitution, law, by-law acts, etc.) as the source of the violation which continued to serve as the ground for further violation of rights and freedoms in similar situations. By this, the given state continues to violate the ECHR as its obligation to respect this Convention is not consistently followed by executing the decision in the part related to a possible compensation since it keeps the validity of the provisions of the general act serving as the source of future violations of rights and freedoms guaranteed by the ECHR. For example, in the cases Sejdić-Finci vs. BH the state of BH is obliged to compensate the appellants for them not being able to run for the Presidency and House of Peoples of BH due to their ethnic affiliation, which the government did. However, more than six years have passed since the decision in the case of Sejdić-Finci was brought and the state of $\mathrm{BH}$ has still not regulated its domestic law in such a way to eliminate further discrimination on the grounds of ethnicity, pointed to by the decision of the ECtHR. A similar situation is evident for numerous decisions brought in other cases where the respondent state executed the decision of the ECtHR in the segment related to the compensation of material and non-material damage to the appellants for the violation of their rights guaranteed by the ECHR but did nothing specific to change its legislative and practice of its bodies so as to prevent the violation of the provisions of the ECHR in similar cases in the future. In its decisions when mentioning the argument relevant for its competency, the ECtHR included the practice in similar cases previously made against the respondent state which ended in the acceptance of the claim in terms of establishing the violation of the ECHR provisions in an identical way. In such cases the given state violates not only the international obligation it took along with the applicable provisions of the international treaty law but also its own legal order in the segment in which the norms included in the ratified international agreements are the part of its legal order.

Therefore, every contracting state has the indisputable obligation to provide strict respect of rights and freedoms defined by the ECHR, bearing in mind that the ECHR provisions are implemented in every country in accordance to its internal legislature which may, apart from other things, be the result of tradition. However, bearing in mind the abovementioned, it is also indisputable that the party states of the Convention should adhere to certain viewpoints of the ECtHR in terms of minimum standards required in the process of internal establishing the legal norms for human rights and freedoms defined by the ECHR and its Protocols, even in individual cases and in the cases where the states were not the respondent party in concrete procedures. It is evident that there is no legal obligation for the implementation of the decision brought by this Court in an individual proceeding against another state. However, one needs to distinguish between the rights and obligations of the parties in the procedure established by every specific decision with an individual character and the opinions of the ECtHR in terms of the interpretation of the ECHR provisions serving as the basis for the decisions in individual civil procedures that have the general character and scope for all the states that are the parties of this Convention. These opinions, apart from highly exceeding the individual importance and plaintiff's interest, also serve as a kind of sui generis interpretation of the ECHR provisions. Such interpretations, regardless of them being given in the form of individual decisions, should be taken into account by all the ECHR signatories, precisely due to the fact that they serve as an authentic interpretation of its provisions given by the Court with the jurisdiction accepted by the states' commitment by the international law and the body which acts as a supreme authority when it comes to ECHR interpretation and implementation. This imposes the obligation onto the signatories of the ECHR for constant observation of the opinions of the ECtHR in terms of the interpretation of ECHR provisions and for taking specific actions in the field of related legal jurisdiction. In that context, ignoring the practice of the ECtHR cannot be considered acceptable from the aspect of appropriate implementation of the ECHR within the domestic legal order. It is not an acceptable option from the aspect of international treaty law as well, or from the aspect of 
obligations that every signatory state took by ratifying the ECHR and its Protocols. It is indeed difficult to expect such full responsibility from any state towards the international obligations it took, particularly referring to massive decision making mechanisms involved in norm-setting function. In such cases, any state signatory to the ECHR can be in a position to face a lawsuit before the ECtHR against its citizens. The chances are then higher of the state losing the lawsuit and being declared responsible for violating the rights and freedoms defined by the ECHR in the cases when there is a clear opinion of the ECtHR on certain issues.

\section{Status and Rights of the Persons in the Same Sex Union in Bosnia and Herzegovina}

The BH Constitution guarantees the right to marriage and forming a family in a general and gender-neutral way. Thus, Article II/ $3 \mathrm{j}$ ) of the Constitution of BH states "All the persons on the territory of BH enjoy human rights and freedoms specified in Section 2. of this Article, including ... j) Right to marriage and to found a family". Section 2.referred to in the previous quoted Article of the Constitution of BH states "The rights and freedoms set forth in the ECHR and in its Protocols shall apply directly in BH. These shall have priority over all other law" (Chandler, 2000; Biber, 2006; Trnka, 2006; Vehabović, 2006). As evident in the stated and quoted norms, the BH Constitution does not provide more detailed regulations in terms of a more precise definition of what is considered a marriage and what is considered a family, but it leaves this issue to be regulated by the legislators at the lower level of government with the jurisdiction in the field of marital and family relationships (entities and Brčko District).

Hence, the Constitution of $\mathrm{BH}$, apart from prescribing direct implementation of the ECHR and its Protocols in Article $\mathrm{II} / 2$ and the priority over all other laws, in its following article emphasizes, among other things, the obligation of respecting the right to marriage and forming a family referring in this article to the ECHR and its Protocols. Bearing in mind the subject matter in this paper, particular importance should be given to the provision of Article II/4 of the Constitution of $\mathrm{BH}$ that prohibits any discrimination on any grounds including gender or sexual orientation when it comes to exercising the rights guaranteed by the Constitution of $\mathrm{BH}$, ECHR and its Protocols, and other international instruments for the protection of human rights and freedoms as defined in Annex I of the Constitution of BH.

When it comes to the implementation of the ECHR and its Protocols within the country's constitution, BH is a specific case. As mentioned previously, the ECHR is a part of the legal order of BH by virtue of its Constitution and it has the priority in implementation over all other laws. This actually means that the ECHR provisions are valid by virtue of inner law or the Constitution of BH. However, BH ratified the ECHR in 2001, thus additionally committing to respect and implement its provisions by international law as well. In addition, as early as in 2005, BH ratified Protocol 12 of the ECHR forbidding any type of different treatment and discrimination in terms of exercising the rights and freedoms guaranteed by the ECHR and its Protocols. Article 1. of this Protocols specifies/prescribes the so called general non-discrimination principle as follows: “ (1) The enjoyment of any right set forth by law shall be secured without discrimination on any ground such as sex, race, colour, language, religion, political or other opinion, national or social origin, association with a national minority, property, birth or other status. (2) No one shall be discriminated against by any public authority on any ground such as those mentioned in paragraph 1."

This provision can be interpreted as absolute zero tolerance for the exclusion from the right guaranteed by the domestic law for any group of persons, whereby the right to family life of the persons is same sex unions can in no way be considered an exception but quite contrary, especially when the practice of the ECtHR is concerned in this matter.

BH is a country with a complex inner organization and it consists of two entities, Federation of BH (FBH) and Republic of Srpska (RS), and Brčko District. Complex constitutional structure is a consequence of Washington and Dayton peace agreements imposed with aim to stop the war (Steiner, 2000; Caspersen, 2004; Papayoanou, 1997; Cox, 1998; Graham, 1998; Schneckener, 2002). As the constitutional division of competencies determines, the jurisdiction for passing the law in the field of marital and family relations rests upon the entities and Brčko District. As a result, marital and family relations in BH are regulated by three different laws: Family Law of FBH, Family Law of RS and Family Law of Brčko District. All three laws recognize and provide detail regulations of marriage and common law marriage of heterosexual persons, whereby heterosexuality of marriage and common law marriage partners, as regulated by these laws, is set as an imperative condition for contracting a marriage or legal recognition of common law marriage in $\mathrm{BH}$.

Such legal situation might be interpreted in several ways. The first includes the interpretation that homosexual persons are not entitled to any rights pursuant to the valid laws that, as an imperative condition for contracting a marriage or recognizing common law marriage, determine different gender of the partners. Such approach would 
actually mean neglecting the fact that the ECHR and its Protocols are an integral part of the legal system of BH by virtue of the Constitution itself and that their provisions are more effective than any other laws, including the abovementioned laws of the entities and Brčko District, which regulate the field of marital and family relations.

This would also mean neglecting the fact that BH ratified the ECHR as early as in 2001 an four years later its Protocol 12 which prescribes absolute non-discrimination. Hence, these act are legally valid in BH not only by virtue of the Constitution or the inner law, but also based on the international treaty law which imposes strict implementation of international treaties the country has signed. This is the obligation imposed by the BH Constitution whose Article III/3 b) specifies that the general principles of international law are an integral part of the legal order of BH and its entities. One of these is pacta sunt servanda principle that prescribes as obligatory the strict and complete execution of international treaty obligations in "good faith". In terms of the legal scope of this principle in $\mathrm{BH}$ and the interpretation of this provision of Article III/3 b), the BH Constitutional Court took a position in the case U-5/09 as follows "Article III/3 b) of the Constitution of BH is violated in the situation when the domestic law is not harmonized with the provisions of the general rule of the international law pacta sunt servanda which stipulates that «Every valid treaty is binding for its signatories/parties and they are to execute it good faith», even when it is not harmonized with the provisions of the international treaty signed by BH."

Therefore, there is an evident legal obligation of the authorities in BH (entities and Brčko District) related to the recognition and legal regulation of same sex civil unions in BH. Such obligation stems from the act of highest legal force in $\mathrm{BH}$ - its Constitution, and is based on the international law as well in terms of appropriate implementation of the provisions of the ECHR and its Protocols that are valid in $\mathrm{BH}$, along with respecting the opinions of the ECtHR as the supreme authority for the interpretation of the provisions included in these acts.

Regarding the issues covered by the subject matter of this paper, the ECtHR took a very clear view - same sex unions, pursuant to the provisions of Article 8. of the ECHR which guarantees the right to private and family life, need to be legally recognized and regulated in the countries where the ECHR and its Protocols are the valid law. The level of rights to be recognized by countries to the persons in same sex unions is left for every single country to decide, but such rights cannot be less than those granted to the persons in common law marriage.

Hence it can be concluded that the lack of the legal regulations in BH treating same sex unions seriously endangers the rights of this population. The very fact that there is a legal gap in the field of same sex unions represents the violation of the Constitution of BH and Article 8 of the ECHR in ref. to Article 1. of Protocol 12, pursuant to the interpretations of the ECHR and its Protocols given in many decisions of the ECtHR. The lack of legal regulations in this field may mean the actual failure for the persons living in same sex unions to exercise minimum rights guaranteed to them by the BH Constitution and the ECHR, in individual cases before the public authority bodies in $\mathrm{BH}$. These bodies, judicial in particular, need to take into consideration in all the current cases or the future ones the fact that when it comes to the rights of persons in same sex unions that the legislative gap does not mean that there is a legal gap. In other words, their rights are guaranteed by the BH Constitution and the ECHR and its Protocols valid in BH. The fact that there are no legislative regulations comes as the result of entities and Brčko District neglecting their obligation to harmonize and pass the laws in this field. Therefore, the lack of legislative regulations in this field can in no way be considered as a valid argument for the Constitution-based rights of persons in same sex unions are neglected and not respected in individual cases before the authorities. In that sense, government bodies should, in their decisions at an individual level, respect at least minimum standards specified by the decisions of the ECtHR in terms of respecting the right to private and family life, Article 8. of the ECHR in ref. to Article 1 of Protocol 12 and Article II/2, II/3 k) and II/4 of the Constitution of $\mathrm{BH}$.

This is further strengthened by the provisions of the Law on Gender Equality in $\mathrm{BH}^{15}$ passed at the state level, with the legal effect on the entire territory of BH. Thus, Article 2 Section 2 of this Law stipulates "Full gender equality is guaranteed in all segments of the society, including but not limiting to the spheres of education, economy, employment and labor, social and healthcare, sports, culture, public life and the media, regardless of the marriage and family status". Section 3 of this Article prohibits any type of discrimination on grounds of gender and sexual orientation. Article 3 Section 1 of this Law further stipulated that gender discrimination includes any unfavorable position of any person or group of persons on grounds on gender, which results in such persons or group of persons experiencing difficulties or full neglect in recognizing, enjoying or exercising human rights or freedoms. This and other provision of the Law on Gender Equality need to be interpreted with reference to the provisions of the BH Constitution and the ECHR and its Protocols, following the interpretations

\footnotetext{
${ }^{15}$ Act on Gender Equality („Official Gazette of BH“, no. 16/03, 102/09). About gender equality in BH see: Boris Krešić, Development of Rights of Homosexual Persons in Bosnia and Herzegovina, International Journal of Law, Policy and the Family (2014) 28(1): pp. 48-59.
} 
of the ECtHR in terms of the right to private and family life. Hence, any action by the authorities in individual cases including non-recognition of same sex unions, failure to recognize their rights or recognition of their rights below the specified minimum might be interpreted as bringing them into a more unfavorable position or discriminating them on grounds of gender orientation pursuant to Article 3. Section 1.of the Law on Gender Equality in BH.

Another law in force in BH is the Law on Banning Discrimination, also passed at the state level and valid on the entire territory of the country. In terms of Article 2.Section 2. of this Law, discrimination is interpreted as any different treatment, including any exclusion, limitation or priority given to any person or group of persons on grounds of, among other things, gender/sex orientation, as well as any other circumstance aimed at preventing or threatening the recognition and exercising on equal grounds the rights and freedoms in all spheres of public life. What needs to be considered here is that the previous recognition of rights resulting from the private-public relations (such as the rights to private and family life in same sex unions) is also the necessary prerequisite for the equal exercising of other rights and freedoms evident in the sphere of public interest. For example, the right to pensions of the deceased partners, tax reliefs for property transfer, inheritance rights for the persons in same sex unions, etc.,all depend on the previous recognition of same sex unions within the legal order.

Consequently, the non-existence of a special law that would recognize same sex civil union and define the rights of persons living in such unions implicitly means bringing this group of persons into an unfavorable position. However, this certainly cannot be seen as ignoring the fact that in BH their rights are guaranteed by the acts bearing more legal power than the law itself (Constitution, ECHR and its Protocols), and as such they represent the value recognized and protected by the legal order of $\mathrm{BH}$. Therefore, the authorities in $\mathrm{BH}$, including judicature, are obliged to make such decisions in individual cases led before them so as to provide minimum rights to the persons in same sex civil unions, until the special laws are brought that would regulate this sphere. This would serve for filling the legal gap currently existing in the regulation of this domain. It is also the obligation emanating from the $\mathrm{BH}$ Constitution as the act with the supreme legal power as well as from the provisions of the ECHR and its Protocol 12, as mentioned before.

\section{Private International Law Aspect of Same-Sex Unions in BH}

From the perspective of comparative law, there are different modifications of the recognition of same sex unions worldwide, including the recognition of same sex marriage, which is by its effects completely equal to heterosexual marriage, as well as various forms of cohabitation, whereby the persons living in same sex civil unions are given a certain scope of rights (Wautelet, 2012; Orejudo Prieto de Los Mozos, 2006; Fiorini, 2003; Tan, 2003; Beilfuss, 2004; Martiny, 2012.). According to the past practice of the ECHR, the countries signatories to the ECHR are obliged to pass the laws that would recognize such persons certain level of rights, which has been left for every individual country to define. However, the level of such rights shall not be lower than the rights of heterosexual persons living in common law marriage. The non-existence of a special law that would regulate the rights of same sex partners in $\mathrm{BH}$ is direct violation of the Constitution of $\mathrm{BH}$, ECHR and its Protocols, valid in BH.

On the other hand, more frequent migrations of the population necessarily involve "import" or "export" of certain legal aspects, including the recognized same sex unions. In other words, the presence of foreign citizen in $\mathrm{BH}$, who contracted a same sex union (regardless of its form) in some other country or intends to contract it in $\mathrm{BH}$, certainly opens specific issues in the domain of private international law.

From the perspective of $\mathrm{BH}$, whose society is rather conservative and based on often wrong values that are strongly intertwined with the religious dogmas, it is certain that most laymen as well as legal professionals have a negative attitude on this issue. When defending their attitude, the latter would certainly invoke the institute of ordre public. However, bearing in mind the above elaborated constitutional-legal/convention solutions valid in $\mathrm{BH}$ as well as the imprecise formulation of the institute of ordre public in the Act on Resolving Conflicts of Laws with Legal Provisions of Other Countries in Certain Relations (hereinafter: the PIL Act BH) ${ }^{16}$, it is worth considering the grounds of invoking this institute (ordre public) in terms of preventing these persons to exercise

\footnotetext{
${ }^{16}$ Official Gazzete of the SFRY No. 43/1982, 72/82, Official Gazzete of the Republic of Bosnia and Herzegovina, No. 2/92, 13/94.Article 4 PIL Act BH: „The law that provisions of this Act instruct to use shall not be used if the effects of its use would be contrary to the legal system of Bosnia and Herzegovina."Article 91 PIL Act BH:"A foreign court decision shall not be recognized if the effect of its recognition would be contrary to the public order of Bosnia and Herzegovina."
} 
their private, mainly property rights in $\mathrm{BH}$. In terms of these issues, the appearance of foreign citizens before the legal bodies in $\mathrm{BH}$, would most often be due to the following reasons ${ }^{17}$ :

1) recognition/registration of the same sex civil union (regardless of its form) in $\mathrm{BH}$,

2) existence of same sex civil union as a preliminary issue, and

3) Recognizing the effects of court order/decision related to the rights of same sex partners.

Although the legal interest in registering/recognizing same sex civil union in $\mathrm{BH}$ may be rare $^{18}$, the recognition of same sex civil union for the purpose of registration in domestic registers is faced with split views in the legal theory of this region (Knežević and Pavić, 2005).

The first view interprets the registration of same sex civil unions as the subject to the provisions of the PIL Act $\mathrm{BH}$ referring to the recognition and enforcement of the judgments made by foreign court. Bearing in mind the legally defined conditions (Muminović, 2006; Stanivuković and Živković, 2013; Alihodžić, 2012) that need to be cumulatively fulfilled, public document does not satisfy these conditions, which is primarily related to the condition of validity as specified in Article 87 of the Private International Law.

This would mean that the legal provisions valid for foreign court and administrative decisions would analogously be implemented for foreign public documents including those issued for same sex civil unions (the appropriate certificate of the registration).

The other, more liberal view sees the foreign certificate of the registration of same sex civil union as a foreign public document with two conditions fulfilled in order to be valid in domestic legal system: reciprocity and authenticity certification (legalization).

As $\mathrm{BH}$, despite its constitutional and international obligations, has still not passed the law to regulate same sex civil unions, it is evident that any potential requests for the registration of same sex civil unions in the registers of marriages in BH shall probably be denied. Namely, these registers of marriages are kept for the registration of heterosexual marriages as defined by the Family Law $\mathrm{Act}^{19}$, and not of same sex civil unions or heterosexual common law marriages.

Another issue to be discussed is the situation when apart from the main proceedings, the status of same sex partner emerges as the preliminary question. Let us use the example mentioned in the article by Knežević and Pavić who, put this problem in the context of the realization of inheritance rights of the same sex partner. Assuming that decuius is the citizen of a country recognizing same sex marriage or other form of same sex civil union, with the property in $\mathrm{BH}$, the possibility for the other same sex partner to inherit the property of the deceased depends on deciding on the preliminary question - the existence of the same sex civil union in the past. As this example is connected to inheritance-related legal relation, pursuant to $\mathrm{BH}$ choice of law rules, the law of the country whose citizen the testator was when death occurred would be considered applicable. Since the person's lex nationalis recognizes same sex civil union, there is a possibility for the realization of the rights of same sex partner. However, there is an obligation of the discussion before a court in BH whether a potential heir is considered "marital partner" or the partner in other recognized form of same sex civil union. According to the court practice in BH (Knežević and Pavić, 2005), existence of marriage cannot be prejudged. For the persons in same sex civil union to be in a position to exercise their property rights, we believe that such a rigid view should not be kept when it comes to the legal relation existing in the past with the resulting actual property effects (Knežević and Pavić, 2005). Such legal regulations objectively exist between same sex partners. In addition, domestic courts should not be allowed to neglect the fact that the rights of this category have the grounds in their national laws.

In terms of recognizing and enforcing the judgments connected to same sex civil unions, the effect of the institute of legal order is largely impaired in relation to invoking ordre public when it comes to the application of the foreign law before the bodies in BH (Dika, M. (et.al.), 1991).Invoking the institute of public order so as to

\footnotetext{
${ }^{17}$ In fact, with these three could be raised the question of marriage or registering the partnership of foreigners of the same sex before the officials in BH. However, both in domestic and in the case of foreign nationals, BH has failed to pass the Act that would make it possible. The previously mentioned must be connected to the lack of the special Act regulating same-sex marriage or registered partnership in BH, having in mind that solutions provided by the Constitution of BH, the ECHR and its Protocol give opposite perspective.

${ }^{18}$ Before the Registry Office in Tuzla, in 2012 appeared an informal request for registration of same-sex marriage concluded abroad. The application was never submitted in written form, and remained at the level of gathering information on the possibility of its implementation. Data from the Registry Office of the Municipality of Tuzla, BH.

${ }^{19}$ According to constitutional division of powers, there are enacted three Family Law Acts in Bosnia and Herzegovina: Family Law Act of the Federation of Bosnia and Herzegovina, Family Law Act of the Republic of Srpska, and Family Law Act of Brcko District.
} 
prevent the effect of foreign court decision on the domestic territory is possible should the effects or the consequences of the recognition of such court decision be intolerable for the country to recognize it. It is understandable since these decisions mainly involve the realization of their property effects on the territory of BH (Knežević and Pavić, 2005). In addition, such relations are mainly regulated by provisions freely disposed by parties. Bearing all this in mind in terms of constitutional and convention-related solutions valid in $\mathrm{BH}$, which serve as the basis of the ordre public institute, it is clear that there are small chances of rejecting the recognition of the decisions made by foreign courts regarding same sex civil unions in procedures before the courts in $\mathrm{BH}$.

\section{Conclusion}

The ECHR is an integral part of the Constitution of BH. BH has also ratified Protocol 12 of the ECHR prohibiting any form of different treatment or discrimination in terms of exercising the rights and freedoms guaranteed by the ECHR and its Protocols.

The European Court of Human Rights is the supreme court authority for the interpretation of the provisions of the ECHR and its Protocols. These views are seen as a sort of sui generis in terms of the interpretations of the ECHR provisions. Such interpretations, regardless of them being given in the form of individual decisions, should be taken into consideration by all the countries signatories to the ECHR, precisely due to the fact that they represent an authentic interpretation of its provision by a court body whose authority the countries accepted by their commitment by international law and the body representing the supreme authority when it comes to the interpretation and implementation of the ECHR.

The ECTHR, by the interpretation of Article 8 of the ECHR, has expanded the term family to the homosexual persons. The countries are also obliged to provide same sex civil unions with the rights required for a successful function of a stabile emotional civil union or family life. After the Oliary decision, it is evident that the signatory countries are obliged to provide the legal framework for the regulation of status and rights of same sex unions in their societies.

Having analyzed the decisions of the ECTHR in which the Court discussed the right to family life of the same sex persons as well as the non-discrimination on grounds of sexual orientation, the authors conclude that the interpretations of the ECHR provisions by the ECTHR is binding and with a direct effect on the positive law of $\mathrm{BH}$. The authors conclude that the lack of legislative regarding same sex civil unions is seen as the direct violation of the Constitution of $\mathrm{BH}$, due to the fact that the country has a positive obligation to provide same sex persons with the right to family life. Furthermore, it is emphasized that any failure to provide such rights to same sex persons, in ref. to Protocol 12 of the ECHR is also a direct violation of the Constitution of BH. Finally, it is concluded that regardless of the fact that the positive law of BH does not regulate the legal status of same sex civil unions, same sex persons need to enjoy all the rights guaranteed to them by the ECHR, including the right to family life. Consequently, the authorities in $\mathrm{BH}$ are obliged to recognize certain effects of same sex civil unions to the partners that concluded them in some country that recognizes such civil unions, without the possibility to invoke the institute of ordre public.

\section{References}

Alihodžić, J. (2012). Razvoj evropskog međunarodnog privatnog prava: pravci reforme zakonodavstva u Bosni I Hercegovini, Tuzla, pp. 240- 272.

Bieber, F. (2006). Post-War Bosnia: Ethnicity, Inequality and PublicSector Governance, Palgrave Macmillan, pp. 114-120. https://doi.org/10.1057/9780230501379

Caspersen, N. (2004). Good Fences Make Good Neighbours? A Comparison of Conflict-Regulation Strategies in Postwar Bosnia. Journal of Peace Research, 5, 569, 572-583. https://doi.org/10.1177/0022343304045973

Chandler, D. (2000). Bosnia: Faking Democracy After Dayton (2nd ed.). Pluto Press, pp. 90-96.

Cox, M. (1998). The Right to Return Home: International Intervention and Ethnic Cleansing in Bosnia and Herzegovina. The International and Comparative Law Quarterly, 3, 599, 603-615. https://doi.org/10.1017/S0020589300062199

Dika, M. et al. (1991). Komentar zakona o međunarodnom privatnom I procesnom pravu, Beograd, pp. 279.

Fiorini, A. (2003). New Belgium Law on Same-Sex Marriage and its PIL Implications. International and Comparative Law Quarterly, 1039-1049.

Gonzales, B. C. (2004). Non-Marital Cohabitation, Registered Partnership and Same-Sex Marriage in Private International Law: The Spanish Perspective. Yearbook of Private International Law, VI, 185-202. 
Graham, J. (1998). Black Past, Grey Future? A Post-Dayton View of Bosnia and Herzegovina. International Journal, 2, 204, 217-220.

Krešić, B. (2014). Development of Rights of Homosexual Persons in Bosnia and Herzegovina. International Jurnal of Law, Policy and the Family, 48-59.

Martiny, D. (2012). Private International Law Aspects of Same-Sex Couples under German Law. In Legal Recognition of Same-Sex Relationships in Europe (K.Boele-Woelki/A.Fuchs) (pp. 189-221). Intersentia.

Muminović, E. (2006). Procesno međunarodno privatno pravo. Sarajevo, pp. 88-89.

Orejudo, P. P. de L. M. (2006). Private International Law Problems Relating to the Celebration of Same-Sex Marriages: DGRN of 29 July 2005. Yearbook of Private International Law, 8, 299-306.

Papayoanou, P. A. (1997). Intra-Alliance Bargaining and U.S. Bosnia Policy. The Journal of Conflict Resolution, 1, 91, 101-109. https://doi.org/10.1177/0022002797041001005

Schneckener, U. (2002). Making Power-Sharing Work: Lessons from Successes and Failures in Ethnic Conflict Regulation. Journal of Peace Research, 2, 203, 209-210. https://doi.org/10.1177/0022343302039002004

Sekelj, L. (2000). Parties and Elections: The Federal Republic ofYugoslavia. Change without Transformation. Europe-Asia Studies, 1, 57, 63, 67. https://doi.org/10.1080/09668130098262

Stanivuković, M., \& Živković, M. (2013). Međunarodno privatno pravo. Beograd, pp. 448-463.

Steiner, M. (2003). Seven Principles for Building Peace. World Policy Journal, 2, 88-90. https://doi.org/10.1215/07402775-2003-3010

Tan, Y. (2003). New Forms of Cohabitation in Europe: Challenges for English Private International Law, in: Perspectives for the Unification and Harmonization of Family Law in Europe, Intersentia, pp. 437-461.

Trnka, K. (2006). Ustavno pravo, Fakultet za javnu upravu, pp. 109-167.

Vehabović, F. (2006). Odnos Ustava Bosne i Hercegovine i Evropske Konvencije za zaštitu ljudskih prava i osnovnih sloboda, Acips, pp. 52-104.

Wautelet, P. (2012). Private International Law Aspects of Same-Sex Marriages and Partnership in Europe Divided We Stand? In Legal Recognition of Same-Sex Relationships in Europe (K.Boele-Woelki/A.Fuchs) (pp. 143-189). Intersentia.

\section{Copyrights}

Copyright for this article is retained by the author(s), with first publication rights granted to the journal.

This is an open-access article distributed under the terms and conditions of the Creative Commons Attribution license (http://creativecommons.org/licenses/by/4.0/). 